\title{
CAPORALATO. AN AUTHENTIC AGROMAFIA
}

\author{
Caporalato. Uma autêntica agromáfia
}

\author{
FANIZZA, Fiammetta; OMIZZOLO, Marco. \\ Milan: Mimesis, 2019, 99 p.
}

Fabio Perocco*

The book "Caporalato. An authentic agromafia" by Fiammetta Fanizza and Marco Omizzolo analyses the presence and rooting of organized crime within Italian agriculture, especially in some regions of Southern Italy, supporting a very interesting thesis: caporalato is not a mere practice of illegal intermediation of workforce, but rather a fully-fledged system which is the core of the activity of organized crime in the field of agriculture and lies on harsh life and work conditions imposed on immigrant farm labourers. A method of individual exploitation and social subjugation of local economies, the caporalato is the beating heart of agromafia, it is an agromafia, thus any debate or action which does not consider such feature will fail.

As an old practice of the countryside, caporalato has been converted and given a central role in the organization of the agricultural sector. The authors highlight the control and illegal management of all phases of production, harvest, processing, distribution and sale of agricultural products, which affects part of the sector; they state that the illegal management of several ambits - from the organization of labour to the control of fruit and vegetable markets, from the determination of the prices to the transport of agricultural products - make it a pervasive, crucial and structural factor, with which workers, agricultural entrepreneurs, processing plants, large retail and transport companies and local communities will have to come to terms. It is a "structured criminal model" with serious economic, political, social and cultural consequences on the whole country, especially in the areas most affected by the phenomenon; such "criminal regime that utilizes an organized hierarchical network that operates throughout the national territory" (p. 13),

Ca' Foscari University of Venice. Venice, Italy. E-mail: fabio.perocco@unive.it. Orcid: 00000003-0991-0046. 
has rooted in contexts of economic marginalization but it has spread all over Italy, including the wealthiest areas of the North. It is a perfect example, I would add, of the concept of entrepreneurial mafia (mafia as a business enterprise), presented by Pino Arlacchi (1983), referring to crime, organized as a company, which has become very skilled, especially in financial operations or in relations with the economic and political worlds.

The authors underline how this happened simultaneously with the expansion of mafias within the Italian society (thanks to several complicities) and the internationalization of crime. It shall be added that this is linked also to the exponential global growth both of organized crime and illegal economy, organically twinned with the legal economy in the grey area of "legal-illegal economy" (Becchi, Rey, 1984) which has grown all over the world. Such aspects deserved a more in-depth analysis, especially at theoretical level, as organized crime and illegal economy are a structural element of capitalistic economy, they carry out specific "functions" within the market economy (they are not always "anti-economy").

The authors highlight another crucial element of the global context: the globalization of the countryside. It is the process that Berlan (2002), in my view, wittily assessed with the concept of "California model", characterized by the application of toyotist methods, a marked capitalistic acceleration and maximization of profits. The hourglass mechanism of the world's agribusiness - brilliantly described by Patel (2008) and reported by the National Farmers Union (2005) - sees on one hand the producers, and on the other hand the consumers, while in between there are corporations in chemistry, mechanics, pharmaceuticals, genetics, distribution, who extract profits; such mechanism forces farmers and breeders to compress their work conditions, and to increase exploitation (for themselves and others, sometimes with dramatic outcomes [Shiva, 2006]). In such global agri-food supply chain, immigrant workers are often the weakest, most compressed and exploited element, which bears the most acute pressure of the production system; in the meantime they have a crucial role, as their exploitation, as the authors point out, is an "implied presupposition (...) a structural prerequisite for rural economy in the 21st century" (p. 16). This exploitation is made possible by - and this point would require more strength - repressive and restrictive migration policies which, by harshly worsening the conditions of migration, make available for the labour market a mass of vulnerable workers, liable to be blackmailed (Basso, Perocco, 2003).

The authors show how caporalato lies upon a severe labour exploitation, physical segregation, housing ghettoization, and social isolation of immigrant farm labourers. This is favoured by several factors, among which I would include the rise of institutional racism (Basso, 2010), besides the presence of 
organized crime offering work occasions and basing its power on violence. Organized crime controls this workforce with an iron fist, it intimidates and attacks immigrant workers demanding their rights and decent work conditions, as demonstrated by the slaughters in Rosarno and Castelvolturno (Borretti, 2010). On this situation, the authors offer and outline a new model of multicultural welfare.

Rich in documents, this very good book is enlightening to understand the framework in which the condition of severe labour exploitation and segregation of immigrant farm labourers is created, especially in Southern Italy. A condition that for the authors constitutes a new social issue at national level, which I believe shall be dealt with a global, serious approach, for a thorough social transformation: fundamental values are at stake, as well as the well-being of local societies, and especially the life of workers which cannot be sacrificed in the name of profit, economic growth or the status quo.

\section{Bibliografia}

ARLACCHI, Pino. La mafia imprenditrice. L'etica mafiosa e lo spirito del capitalismo. Bologna: Il Mulino, 1983.

BASSO, Pietro; PEROCCO, Fabio (eds.). Gli immigrati in Europa. Disuguaglianze, razzismo, lotte. Milan: Angeli, 2003.

BASSO, Pietro (ed.). Razzismo di stato. Stati Uniti, Europa, Italia. Milan: Angeli, 2010.

BORRETTI, Biagio. Da Castel Volturno a Rosarno. Il lavoro vivo degli immigrati tra stragi, pogrom, rivolte e razzismo di stato. In: BASSO Pietro (ed.). Razzismo di stato. Stati Uniti, Europa, Italia. Milan: Angeli, 2010, p. 493-524.

BECCHI, Ada; REY, Guido. L'economia criminale. Roma-Bari: Laterza, 1984.

BERLAN, Jean-Pierre. La longue histoire du modèle californien. In: Forum Civique Européen. Le gôut amer des nos fruits et légumes. Limans: FCE, 2002.

NATIONAL FARMERS UNION. The Farm Crisis \& Corporate Profits, 2005. Available on: <https://www.nfu.ca/policy/the-farm-crisis-corporate-profits $>$.

PATEL, Ray. Stuffed and Starved: The Hidden Battle for the World Food System. London: Portobello, 2008.

SHIVA, Vandana. Seeds of suicide. New Dehli: Navdanya, 2006. 